\title{
8. Geological Age of the Yosida-mura Shell-beds of Kagosima-ken, Kyûsyû. I.*
}

\author{
By Hisakatsu Y ABE, M.I.A. \\ (Comm. Mar. 12, 1946.)
}

I.

In the two short papers, "On Some Brachiopods from Kagosima-ken, Kyûsyû"1) and "On Some Fossil Mollusca from Kagosima-ken, Kvûsyû" ") K. Hatai and the writer several years ago dealt with molluscan and brachiopod remains collected by S. Endo from the shell-beds exposed at Unoki and Kuwanomaru, both in Yosida-mura, Kagosima-ken, and situated very close to each other. The shell beds belong to one and the same horizon in the basal part of a tuff formation, which is as a whole massive, but more or less distinctly stratified in sandy and pebbly parts.

The brachiopods from these two localities are few in number; nevertheless, they represent 4 distinct species, 3 species of the genus Pictothyris and 1 species of Kikaithyris; namely, Pictothyris picta (Dillwyn), P. elegans endoi Yabe and Hatai, P. fortipicta Yabe and Hatai, and Kikaithyris hanzawai (Yabe). $P$. picta is a living species which ranges back to the Pliocene, $P$. elegans endo $i$ is a new subspecies of the living elegans, and $P$. fortipicta is a new species yet found from no other places, either living or fossil, while Kikaithyris hanzawai is a species hitherto known only from Taiwan and Ryûkyû Islands and confined to the Ryûkyû limestone. While Kikaithyris is now a mototypic genus, Pictothyris has one more living species, P. laquaeformis Yabe and Hatai, which is not represented in the Yosida-mura shell-beds. The 4 species of Pictothyris and a Kikaithyris mark a distinctive feature to the present fossil fauna.

Kikaitkyris hanzawai is a characteristic fossil of the Ryûkyü limestone,

* For the present study, the writer spent about a month in March and April, 1945, in southern Kyûsyû, accompanied by Mr. T. Mihara, graduate of the Institute of Geology and Palaeontology, Tôhoku Imperial University, whom he wishes to express his hearty thanks for constant help; thanks are also extended to his families Mihara and Mita of Tyôhu near Simonoseki for the fascilities given and courtesies shown in various ways to the writer during the trip.

The cost of this trip has been defrayed from the Scientific Research Expenditure of the Department of Education.

1) Jour. Geol. Soc. Japan, Vol. XIVIII, No. 575, 1941.

2) Ibid. 
and has been found in no other formation until now; its occurrence in the Yosida-mura shell-beds suggests approximate contemporaneity of these two formations.

On the other hand, the molluscan remains of the Yosida-mura shell-beds are fairly numerous, representing 39 species of bivalves, 2 species of scaphopods, and 36 species of univalves, aitogether 77 species as listed below. Some 15 species of the $19.5 \%$ of the total are not known living in the present seas; if brachiopods be taken into account, this percentage arisès up to 23. The figure, be 20 or 23 , indicates the late Pliocene age of the shell-beds.

List of the Fossil Mollusca from the Yosida-mura Shell-Beds (K. Hatai ident.)

\begin{tabular}{|c|c|c|c|c|c|}
\hline$\cdots$ & Unoki & $\begin{array}{l}\mathrm{Ku}- \\
\text { i wano- } \\
\text { maru }\end{array}$ & & Unoki & i $\begin{array}{c}\text { Ku- } \\
\text { wano- } \\
\text { maru }\end{array}$ \\
\hline Aloides venustus (GoUL.J)) & $x$ & - & P. nipponensis KUROLA & $x$ & - \\
\hline A. scaphoides (Hivis) & - & $x$ & $P$. cf. chosenica KURODA & $x$ & - \\
\hline A. problematica (MARTIN) & $x$ & - & Plicatula horrida DUNKER & $x$ & - \\
\hline Anomia cytaeum GKAY & ? & $x$ & Pinna atropurpurea Sow ERBY & $x$ & - \\
\hline Arca uwaensis (YoKกYAMA) & $\times$ & - & Pseudamusium intuscostatus & & \\
\hline Barbatia fusca (BRUGUIERE) & $\times$ & $\times$ & YOKOYANA & $x$ & - \\
\hline B. decussata (SOWEREr) & - & $\times$ & Spondylus anacanthus MAWE & $\times$ & - \\
\hline B. yokoyamai NCMURA & $x$ & - & Solen goulaii CONRAD & $x$ & - \\
\hline Cardita cumingiana DUNKER & - & $\times$ & Solecurtus divaricatus LiSCHKE & $x$ & - \\
\hline C. variegata BRUGUIKRE & - & $x$ & Venericardia ferruginea (CLESSIN) & $x$ & $x$ \\
\hline Chama aspersa RELVF, & $\times$ & $\times$ & A. ferruginosa (ADAMS and & & \\
\hline Codakia divergens (PHILJPPI) & $\times$ & - & REeve) & $x$ & - \\
\hline Crassatellites namus (A)AMs and & $x$ & $x$ & Volsella trailli (REEvE) & $x$ & - \\
\hline REEVE) & & & Venus puerpera LinNaEus & - & $\times$ \\
\hline Dentilucina cinica (YOKOYAMA) & $x$ & $x$ & V. joveclata SOWERBY & $\times$ & - \\
\hline Dosinia cf. japonica (REEvE) & - & $x$ & V. toreuma GoUl.D & $x$ & - \\
\hline Lima cf. ohshimensis SOWEREY & $x$ & - & Dentalium hexagonum GOULD & $x$ & - \\
\hline Lucina acutilineata CONRAI) & $x$ & - & D. weinkauffi DuNKLR & - & $x$ \\
\hline Nucula tchuis MONTARU & $x$ & - & Ancilla albocaliosa LINNAEUS & $x$ & - \\
\hline Nuculana cf. takaoensis OTUKA & $\times$ & - & Cancellaria cf. taiwanensis & & \\
\hline $\begin{array}{l}\text { Pecten kikaiensis NomlKA and } \\
\text { ZINIO }\end{array}$ & $x$ & - & $\begin{array}{l}\text { NOMURA } \\
\text { Calliostoma sagamianum YoKก- }\end{array}$ & $x$ & - \\
\hline P. tokycensis TokUNAGA & $x$ & - & YAMA, var. & - & $\times$ \\
\hline P. naganumanus YoKnYAliA & $x$ & - & C. unicum (DUNkER) & - & $x$ \\
\hline P. quadriliratus LISCHKE & - & $\times$ & Chrysallida caelata (A. Arims) & $x$ & - \\
\hline P. vesiculosus DUNKFK & $x$ & $\times$ & Chlorostoma rustica (GoULD) & $x$ & - \\
\hline P. hruiser BAVAY & $x$ & -- & Claratula consimilis (SMITH) & $x$ & - \\
\hline
\end{tabular}


Clavus jeffreysii (SмITH)

C. nivaloides (YoKoy AMA)

Columbella burchardi DUNKER

Conus coronatus GMELIN

Cyclostrema micans A. ADAMS

Cypraea vitellus LINNAEUS

Erato callosa (ADAMS and REEVE)

Ficus ficoides (LAMARCK)

Hemifusus ternatanus (GMELIN)

Iravadia annulata (DUNKER)

Lienardia gainesi (PILSBRY)

Mitra flammea QUOY

Nassarius exmius (H. and A.

ADAMS)

Natica concinna DUNKER

Oliva ispidula (LINNAEUS)
O. mustellina LAMARCK

Natica janthostoma DESHAYES

Phos senticosus LinNaEus

Pseudoraphitoma naganumaensis

OTUKA

Pustullaria caputserpentis

(LINNAEUS)

Puncturella hirasei OTUKA

Polinices cf. didymus (BOLTEN)

Siliquaria cumingii MöRCH

Solidula strigosa GoULD

Terebra cf. dussumieri KIENER

Turcica imperialis A. ADAMS.

Trophon subclavatus YOKOYAMA

$T$. cf. nipponicus YOKOYAMA

T. birileffi LISCHKE

\begin{tabular}{c|c}
- & $\times$ \\
$\times$ & - \\
$x$ & - \\
& \\
$x$ & - \\
& \\
$\times$ & - \\
$\times$ & - \\
$\times$ & - \\
$\times$ & $\times$ \\
- & $\times$ \\
$\times$ & - \\
$\times$ & - \\
$\times$ & - \\
$x$ & - \\
$\times$ & - \\
\hline
\end{tabular}

The Ryûkyû limestone with an extended distribution over Taiwan and the Ryûkyû Islands's) does not extend into southern Kyûsyû, its northernmost extension being on Kikai-zima, where S. Hanzawa found a rich fossiliferous limestone, hereafter to be called the Kamikatetu limestone, of the formation on the plateau surface above Kamikatetu; this locality yielded him abundant fossils of mollusca,4) brachiopoda,5) corals $^{6}$ ) and bryozoa. Of the molluscan remains, S. Nomura and N. Zinbo discriminated 74 species of bivalves, 1 species of scaphopod, and 126 species of univalves, -201 species in total, including 22 new species. The percentage of apparently extinct forms to the total number is 13.7, being far less than in the case of the Yosida-mura shellbeds; the two authors regarded provisionally the Kamikatetu limestone fauna as old as the early Pleistocene. These figures 13.7 and 19.5 or 23 , alone taken into consideration, the Yosida-mura shell-beds are likely to be somewhat older than the Kamikatetu limestone.

Corals are very rare in the Yosida-mura shell-beds, ${ }^{7)}$ being represented

3) S. Hanzawa : Topography and Geology of the Riukiu Islands. Sci. Rep. Tôhoku Imp. Univ., Ser. II (Geol.), Vol. XVII, 1935.

4) S. Nomura and N. Zinbo: Marine Mollusca from the Ryûkyû Limestone of Kikai-zima. Ibid., Vol. XVI, No. 2, 1934.

5) H. Yabe: Brachiopods of the Genus Pictothyris Thomson, 1927. Ibid. Vol. XV, No. 3, 1932.

6) H. Yabe and M. Eguchi: Deep-water Corals from the Riukiu Limestone of Kikai-zimi, Riukiu Islands. Proc. Imp. Acad., Vol. VIII, No. 9, 1932.

7) M. Eguchi : On Two Species of Simple Corals from Kagosima.ken, Kyûsyû. Jour. Geol. Soc. Japan, Vol. XLVIII, No. 575, 1941. 
merely by three specimens of small simple corals. Two of these specimens belong to Deltocyathus orientalis Duncan, a species with an extended distribution from the Japanese seas through the Malayan waters and Indian ocean far westward to the Mediterranean Sea; it has a geological range from the Pliocene to the Recent. Another specimen with worn surface is certainly a form of Heteropsammia, identical with or closely similar to $H$. ovalis Semper, now living in the seas from Japan to the Malay archipelago. These two species are common in the Kamikatetu limestone; however, they have no significant bearing on the question now in concern.

The molluscan fauna of the Kamikatetu limestone and the Yosida-mura shell-beds have only a few species in common. This is rather striking in relation to their approximate contemporaneity; perhaps, it is due to the circumstances that the Ycsida-mura shell-beds are shallow water clastic sediments of an enclosed bay, probably larger and more open than the present Kagosima Bay, while the Kamikatetu limestone is a member of a thick limestone complex, the Ryûkyû limestone, and is in itself a shallow-water deposit around coral reefs. In addition, Yosida-mura lying far north of Kikai-zima, it is quite natural that the molluscan fauna of the former has many molluscs of northern type and that of the latter is rich in tropical forms, lacking northern types.

As already pointed out in the paper on this molluscan fauna, its elements of particular interest are Pecten tokyoensis Tokunaga, P. naganumanus Yokoyama, Pseudoraphitoma naganumaensis Otuka, and Pseudoamusium intusicostatum Yokoyama. Pecten tokyoensis is one of the most characteristic fossils of the Pleistocene Narita beds (s. 1., including the Tokyo beds), and P. naganumanus that of the Uppermost Pliocene Naganuma bed. The latter species and Pseudoraphitoma naganumaensis are two characteristic forms common to the Naganuma beds and the present shell-beds, while Pecten kikaiensis and Kikaithyris hanzawai are common to the Kamikatetu limestone and the present shell-beds. Pecten intusicostata is an extinct species known from the Pleistocene Miyata shell-beds of Miura peninsula and the Pleistocene Upper Musasino of the province of Kazusa; it also occurs in the Pliocene Kosiba beds near Kanazawa, Musasi province. These fossils indicate that the Yosida. mura shell-beds can not be much older than the Ryûkyû limestone with Pecten naganumanus and Kikaithyris; the two formations may be approximately contemporaneous, both being youngest Pliocene.

The Massive tuff of Yosida-mura, with the shell-beds in its basal part, is directly underlain by another of tuff and tuffaceous shale, which is thin-layered 
in part. The stratification of the two formations is almost parallel, though they are separated by a distinct, small-scale erosion-unconformity. Whatever the magnitude of the time-gap may. be, it is, at any rate, evident that the former is younger than the latter formation.

K. Yamaguchi, Professor of the Matue High School, who devoted himself throughout more than a score of years to the geological and petrological researches of the region around the Kagosima Bay and the voicano Sakurazima, found fossil plant leaves in the second, that is to say lower, formation from various places within Yosida-mura and its annexed districts. These plant fossils have been studied by S. Endo who subsequently visited these localities and made a large collection : according to his printed report as well as verbal communication, the material he examined is fairly rich; nevertheless, it comprises only a few species, showing the simplicity of the fossil florula in its composition. The plants specifically distinguished by him are:

$\begin{array}{ll}\text { Acer diabolicum Blume } & \text { Prunus } \text { sp. } \\ \text { A. pictum Thunberg } & \text { Quercus } \text { sp. } \\ \text { Carpinus laxiflora Blume } & \text { Salix } \text { sp. } \\ \text { Fagus } \text { crenata } \text { Blume } & \text { Stewartia pseudocamellia Maximuwicz } \\ \text { Juglans } \text { sp. } & \text { Tilia japonica Simonk } \\ \text { Larix } \text { sp. } & \text { Ulmus parvifolia Jacquir } \\ \text { Picea hondoensis Mayr } & \text { Zelkova serrata Makinc }\end{array}$

Of 14 species listed above, 9 species are specifically identified, while the remaining 5 species are indeterminable due to bad preservation. The trees here specified are all now living in Japan.

Aside of very simple composition, this fossil florula has another remarkable aspect, in Zelkova-and more particularly Fagus-leaves overwhelming the other in number, so as Endo pronounced "The original forests which supplied the fossil leaves to the plant beds can be regarded as almost pure beech forests". Further on he stated "The trees of Fagus crenata now are living in the mountains of Kyûsyû and growing at the altitude of about $1000 \mathrm{~m}$ or more; they do not at present exist in southern Kyûsyû, except Mt. Takakuma. In the main island, Honsyû, they now enjoy a luxuriant growth in the $\mathrm{Cfb}$ conditions of Köppen climate formula, while the fossil localities mentioned above are in his Cfa climatic field; it involves therefore a climatic change from Cfa to $\mathrm{Cfb}$ occurred there between geological date indicated by the fossil flora and the present day". This conclusion by Endo deserves special attention.

8) S. Endo: A Pleistocene Flora from Kagosima, Kyûshû, Japan. Jour. Geol. Soc. Japan, Vol. XLVI, No. 547, 1939. 
An additional note may be of need in this connection, namely that the plant beds occassionally contain marine fossils; Endo found generically indeterminable echinoids and bivalves of the genus Lucina at Haginozyô, Sigetomi-mura and an echinoid identified by S. Nisiyama with Brisopsis latifrons Agassiz, a living species of the Japanese seas, at Gotanda, Yosida-mura, in association of plant leaves in the deposits. The deposition of the plant beds certainly took place under a calm water of lagoons near sea-shore, and not in mountain lakes.

As to the geological age of the fossil florula, Endo had no hesitation about its Pleistocene age; this is a conclusion quite natural and reasonable, seeing that its composition is of living species only, without association of any exotic or extinct ones.

The lower formation entombs a fossil florula with a younger aspect and the upper a fossil fauna with an older aspect. 